REPORT

\title{
Exploring Group Study At the University of Nevada, Reno
}

October 8, 2015

Ann Medaille

Molly Beisler

Tara Radniecki

Maggie Ressel

Heidi Slater

Danielle Cooper

Nancy Fried Foster

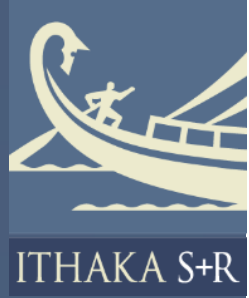




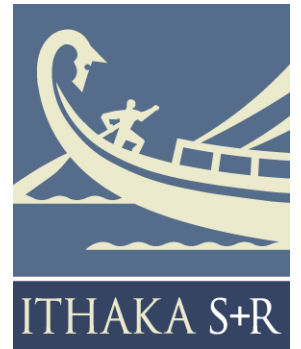

Ithaka $\mathrm{S}+\mathrm{R}$ is a strategic consulting and research service provided by ITHAKA, a not-for-profit organization dedicated to helping the academic community use digital technologies to preserve the scholarly record and to advance research and teaching in sustainable ways. Ithaka $\mathrm{S}+\mathrm{R}$ focuses on the transformation of scholarship and teaching in an online environment, with the goal of identifying the critical issues facing our community and acting as a catalyst for change. JSTOR, a research and learning platform, and Portico, a digital preservation service, are also part of ITHAKA.
Copyright 2015 ITHAKA. This work is licensed under a Creative Commons Attribution-NonCommercial 4.0 International License. To view a copy of the license, please see http://creativecommons.org/licenses/by-nc/4.0/.

ITHAKA is interested in disseminating this report as widely as possible. Please contact us with any questions about using the report: research@ithaka.org. 


\section{Foreword}

Libraries continually struggle with how to make the best use of their space, and collaborative study spaces have been added to support the perceived requirements for group projects. The University of Nevada, Reno (UNR) wanted to know what kind of spaces students actually need to do their work, and brought in Ithaka S+R's senior anthropologist, Nancy Fried Foster, to help them explore this question. Using the methods of design anthropology, collecting artifacts and conducting interviews, the Ithaka $\mathrm{S}+\mathrm{R}$ and UNR team makes recommendations on ways to meet the academic and social needs of undergraduate students in their context. One of the most important findings of the team is that while collaborative study space is needed, it is not used in exactly the way the librarians imagined. The approach taken by this research team yields rich data about actual uses of space. This study illustrates one of the many ways that ethnographic methods are useful for making decisions about library services.

-Deanna Marcum, Managing Director, Ithaka $S+R$

\section{Introduction}

For more than a decade, college and university librarians have poured resources into accommodating group work in the belief that students are receiving more and more group assignments, especially in STEM fields. And judging by headcounts and casual observation, group spaces have proven successful. Students use study rooms and group tables and ask for even more such space, and many libraries are quick to oblige. However, our study conducted at the University of Nevada, Reno, suggests that only a small proportion of students are engaged in focused, collaborative work on group projects at any given time. ${ }^{1}$ A somewhat larger number of students study with peers and many sit with friends for company. Many students prefer to work alone. Many such interesting findings are included here along with information about the questions and methods of our study and some interesting implications. As we learn more about the nature, frequency, and value of group work, we hope that academic libraries will be able to make better, more informed decisions about the design of facilities and services to support student work practices. This report contributes to that effort.

\footnotetext{
${ }^{1}$ The authors thank Kathlin L. Ray, Dean, University Libraries and Teaching \& Learning Technologies, for her active interest in and support of this project.
} 


\section{Studies of Study Groups}

As background, we looked to a study begun at Brigham Young University in 2005 in connection with the construction of an information commons, in which the object of study was "two or more people talking together in the commons." observational study was to understand the use of the new commons and ensure the ongoing success of several of its offerings, including workstations, classrooms, consultation services, and support for collaborative work. ${ }^{3}$ The Brigham Young team found that the information commons had become a "popular place to study" for individuals as well as groups, ${ }^{4}$ with the number of groups fluctuating but remaining relatively high at different times of day and through the semester and year. ${ }^{5}$

A project at the University of Rochester's River Campus Libraries looked at study groups starting in 2010. The university had initiated "peer-led team learning" in its lower-level chemistry courses, according to study authors, which produced good results as predicted by a large literature on group learning. ${ }^{6}$ The Rochester study looked specifically at study groups comprised of "two or more students who were enrolled in and working on the same course," although they found that only a portion of the groups they approached fit this definition, others being "simply friends sitting together and working on different courses-essentially keeping company while working apart."7 Reflecting on the seven groups they interviewed, some formed voluntarily and others assigned by the instructor, the study team speculated that students participate in study groups to learn material that may seem too hard to master alone. They found that study groups help students do background preparation, keep each other on task, enhance each other's knowledge base, and enhance learning through discussion of the material. ${ }^{8}$ They concluded that many study groups meet in a campus library because the space is available virtually around the clock, affords extended work sessions in comfortable surroundings, is conveniently

\footnotetext{
${ }^{2}$ Michael J. Whitchurch, "Evaluating Group Use of the Information Commons," College \& Undergraduate Libraries 16, no. 1 (March 30, 2009): 71-82, doi:10.1080/10691310902754130.

${ }^{3}$ lbid., p. 72.

${ }^{4}$ Ibid., p. 74.

${ }^{5}$ lbid., pp. 75-81.

${ }^{6}$ Bersani, Alison, Judi Briden, Sue Cardinal, and Katie Clark. "Study Groups in Libraries: Exponential Benefits." In Studying Students: A Second Look, edited by Nancy F. Foster and Susan Gibbons, 123-38. Chicago: ACRL Press, 2013. http://hdl.handle.net/1802/28781.

7 lbid., p. 125

8 lbid., p. 129
} 
placed with respect to other academic buildings, and offers power, $\mathrm{Wi}-\mathrm{Fi}$, reserve materials (especially textbooks), and other desirable resources. ${ }^{9}$

There is a growing body of qualitative case studies that examine how college students use library spaces, often with an eye towards redesigning those spaces. ${ }^{10}$ Some of these studies are particularly noteworthy for challenging typical definitions of what constitutes collaborative work in the library beyond students working on the same task, be it a group project or studying for the same exam. Crook and Mitchell's "Ambience in Social Learning: Student Engagement with New Designs for Learning Spaces,” for example, also observes other activities, including "intermittent exchange," where students converge to study independently but then periodically discuss issues pertaining to their work with the group; "serendipitous encounter," where students have brief exchanges during chance meetings in the library space; and "ambient sociality," where students working entirely independently prefer studying among others. ${ }^{11}$ Similarly, a report by Camille Andrews and Sara E. Wright on student library use at Cornell provides a list of observed student activities in libraries that extend beyond traditional concepts of group work, including "touchdown meetings with TAs or other students, assembling individual project parts created by group members, brainstorming, practicing presentations, working on non-academic projects, [and] studying in proximity." ${ }^{2}$

\footnotetext{
${ }^{9}$ lbid., pp. 131-135. Additional unpublished projects on spaces for group study and study groups, many of them anecdotal, are not reviewed here.

${ }^{10}$ See, e.g., Kylie Bailin, "Changes in Academic Library Space: A Case Study at the University of New South Wales," Australian Academic \& Research Libraries 42, no. 4 (2011): 342-359; Joanna Bryant, Graham Matthews, and Graham Walton, "Academic Libraries and Social and Learning Space: A Case Study of Loughborough University Library," UK Journal of Librarianship and Information Science 41, no. 1 (2009): 7-18; Katharine Hall and Dubravka Kapa, "Silent and Independent: Student Use of Academic Library Study Space," Partnership: The Canadian Journal of Library and Information Practice and Research 10, no. 1 (2015), https://journal.lib.uoguelph.ca/index.php/perj/article/view/3338/3506\#.VcILNvIVhBd; Deborah Harrop and Beatrice Turpin, "A Study Exploring Learners' Informal Learning Space Behaviors, Attitudes, and Preferences," New Review of Academic Librarianship 19, no. 1 (2013): 58-77; Sara Holder and Jessica Lange, "Looking and Listening: A Mixed-Methods Study of Space Use and User Satisfaction," Evidence Based Library and Information Practice 9, no. 3 (2014): 4-27.

${ }^{11}$ Charles Crook and Gemma Mitchell, "Ambience in Social Learning: Student Engagement with New Designs for Learning Spaces," Cambridge Journal of Education 42, no. 2 (2012): 136.

${ }^{12}$ Camille Andrews and Sara E. Wright, "Library Learning Spaces: Investigating Libraries and Investing in Student Feedback" (presentation, ACRL 2015 Conference, Portland, OR, March 25-28, 2015), http://www.ala.org/acrl/sites/ala.org.acr//files/content/conferences/confsandpreconfs/2015/Andrews_Wright.pdf.
} 


\section{Extending Previous Work}

UNR sought to build on this earlier work and gain additional insight on a wide range of issues related to group study. These issues included characteristics and activities of students working in groups of two or more; location and the choice of space; and the use of digital and other technologies and resources. While the project was motivated by curiosity about the use of dedicated study rooms and group tables, it extended quickly to all forms of group work, including assigned projects, voluntary study groups, and even students working together simply to keep each other company. ${ }^{13}$

To meet this information need, a team of five subject librarians at UNR worked with Ithaka $\mathrm{S}+\mathrm{R}$ to plan and implement a project about group study using three low-cost, easy-to-use methods for gathering information. UNR is a land-grant university with undergraduate and graduate programs in the liberal arts and sciences, and professional programs in agriculture, medicine, engineering, health care, education, journalism, and business. The student population in the fall of 2014 was approximately 20,000.

\section{Approach and Methods}

The purpose of this study was to understand and support the work practices of students who are called upon to do collaborative study and group projects. In other words, this project was undertaken in order to support design or redesign, primarily of spaces but also of services. We took a "participatory design" approach and used the methods of work-practice study. Participatory design is a way of engaging the people who will use a space or a service in its design in order to capture expert knowledge of their work practices and needs. Work-practice study refers to a focus on the very activities in which people engage when they accomplish their work. In this case, we were interested in the work practices of students, so we engaged with students using several different methods to gain a better understanding of the extent of their group work and their associated practices. These methods were spot interviews, reply cards, and group study snapshots.

\footnotetext{
${ }^{13}$ We note a significant opportunity to further build on existing research, which we were not able to pursue in this project: to gather information on the degree to which group assignments are made and work groups are assigned or encouraged in a variety of courses and programs.
} 


\section{Spot Interviews}

Spot interviews are brief interviews that are conducted in non-library campus locations where undergraduates tend to walk or cluster. These interviews lasted approximately ten minutes and focused on the respondent's most recent study sessions. The team conducted spot interviews of a total of 86 graduate and undergraduate students. Interviews were conducted outside in non-library locations of high activity, including the student union, the student recreation center, a plaza, and the science quad.

\section{Reply Cards}

Reply cards contain a survey for respondents to complete in a few minutes. The survey included seven questions and requested a very small amount of demographic data. The questions focused on what the individual was doing when interrupted, the reasons for the individual's choice of location, and the individual's recent group work. The team collected cards from 146 individuals across the main library (the Mathewson-IGT Knowledge Center) and the science library (the DeLaMare Science and Engineering Library).

\section{Group Study Snapshots}

Group study snapshots are brief interviews of groups interrupted in the midst of apparently working together in designated group study spaces or in areas that visibly support group work, such as a room with large tables. The team collected data from 46 groups that included 148 total individuals in the midst of their activities, both in the main library and in the science library.

\section{Major Findings}

Our interpretation of the analyzed data focused on a set of questions about the prevalence of group projects and study groups, as well as the conditions under which students are able to accomplish group work. For the purposes of this report, "group project" refers to a group assignment given by an instructor, "working as a group" is used when students are working together on the same task, and "just sitting together" is used when students are not working on the same task. 


\section{Student Activities in the Library}

Most students in the library-almost a third of all respondents to the reply cardsreported that they were studying - that is, going over course material or preparing for an examination or quiz (see Figure 1). Almost another quarter were completing homework assignments. Just over one in ten said that they were socializing, and about the same number were working on a paper. Ten percent reported procrastinating, doing nothing, or taking a break. Other respondents in the library reported being engaged in a variety of activities, including reading, using a computer, and filling out forms.

Figure 1. Student Activities While in the Libraries (Reply Cards)



We conclude that a significant majority of the people in the librariesabout three out of four-are engaged in academic work.

\section{Prevalence of Group Work}

Individuals polled in the libraries were somewhat more likely than those intercepted at non-library campus locations to have worked recently in a group. Eighty-four out of 146 respondents to the reply cards reported that they were sitting with people they knew. Almost half of the respondents (72 out of 146) said that they were working in a group when interrupted or had worked in a group earlier in the day. 


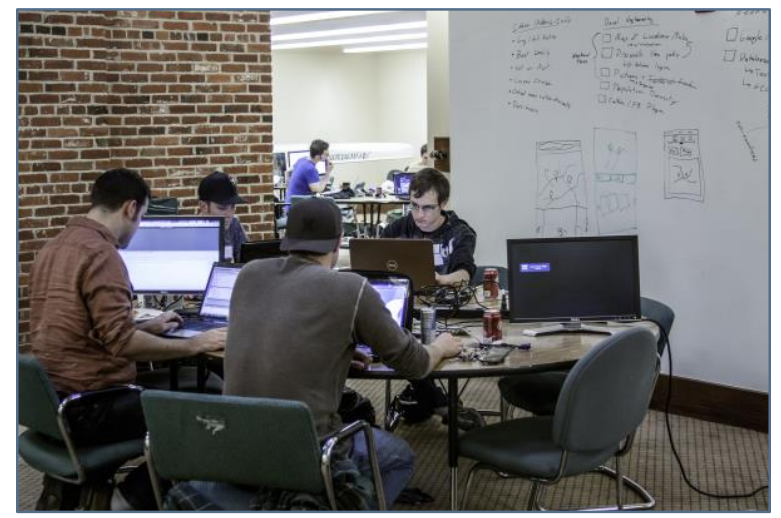

Students at Work in the DeLeMare Science and Engineering Library ${ }^{14}$

Just over a third of the respondents to the spot interviews held at non-library locations (31 of 86) reported having worked with other people during their most recent schoolwork session. Of these 31 students, about half (13) were working on the same thing while the others (18) were just sitting together. Of those 13 who were working on the same thing, half (7) said that they regularly work together. Half (7) were working on an assigned group project or presentation while the others (6) were working on homework or general classwork or studying for a test.

Of those who were not working as a group (i.e., those who were alone or just sitting with others) in the last schoolwork session (73 respondents), over 64 percent had worked on a group project during the current semester. Eighty-six percent reported working on a group project during the last year (see Table 1).

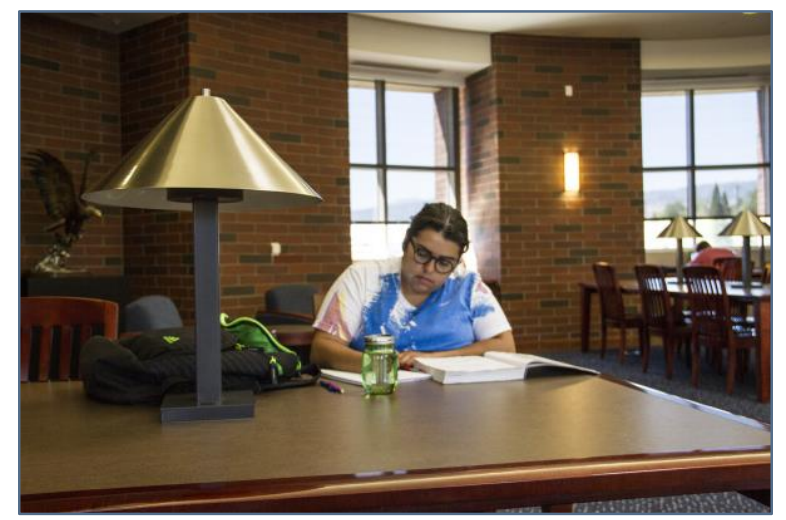

Student in the Mathewson-IGT Knowledge Center

${ }^{14}$ Photographs for this report have been provided by Nick Crowl. 
Table 1. The Last Time That Students Worked on an Assigned Group Project (Spot Interviews)

\begin{tabular}{llc}
\hline Last time of group project & Number & Percent \\
\hline Not now, but in the current semester & 47 & $64.4 \%$ \\
Last semester & 16 & $21.9 \%$ \\
One year ago or more & 4 & $5.5 \%$ \\
Never in college & 6 & $8.2 \%$ \\
\hline Total & 73 & $\mathbf{1 0 0} \%$ \\
\hline
\end{tabular}

Based on the evidence at hand, we conclude that large numbers of students work in groups occasionally, with small numbers regularly needing to work with others on the same project. Greater numbers of students simply prefer to work in proximity to their friends who are engaged in different tasks.

\section{Features of Group Work}

In spot interviews, students conducting research or writing papers in their most recent schoolwork session (17) reported working alone at a much higher rate than those doing any other activity (4). All students (6 of 6) who said they had been doing group work or a group project reported that they had been working with others. Just over a third of the students who reported studying for an exam (5 of 13) or doing homework (11 of 32) said they were working with others. Students who had been engaged in other activities worked with others at a slightly lower rate (see Table 2). 
Table 2. Activities When Working Alone or with a Group (Spot Interviews)

\begin{tabular}{llll}
\hline Activity & Alone & $\begin{array}{l}\text { With } \\
\text { Others }\end{array}$ & Total \\
\hline Group work/group project & 0 & 6 & 6 \\
$\begin{array}{l}\text { Homework/assignment } \\
\text { (includes lab, extra credit) }\end{array}$ & 21 & 11 & 32 \\
$\begin{array}{l}\text { Project (individual) } \\
\text { Reading }\end{array}$ & 2 & 2 & 4 \\
$\begin{array}{l}\text { Studying (general; includes } \\
\text { reviewing notes) }\end{array}$ & 2 & 2 & 6 \\
$\begin{array}{l}\text { Studying for exam } \\
\text { Writing paper/conducting } \\
\text { research }\end{array}$ & 17 & 1 & 3 \\
\hline $\begin{array}{l}\text { Other } \\
\text { Total }\end{array}$ & 1 & 5 & 13 \\
\hline
\end{tabular}

According to the reply cards, the average group size reported by the 79 students who were or had been sitting with others was 2.76. Students who reported being engaged in actual group work or group projects indicated that their groups included 3 or more individuals, a higher average than that of other identified activities, which ranged from a low of 2 (secondary academic tasks, such as filling out applications; taking a break) upwards. Those who reported studying for an exam were in groups that averaged 2.3 individuals, one of the lowest averages. Even those who said that they were socializing reported being in groups of 2.7, lower than those doing group projects or group work. Of those who were or had been sitting with others, 53 percent were sitting in a group of two, 33 percent in a group of three, and 14 percent in a group of four or more (see Figure 2). 
Figure 2. Frequency of Group Sizes (Reply Cards)

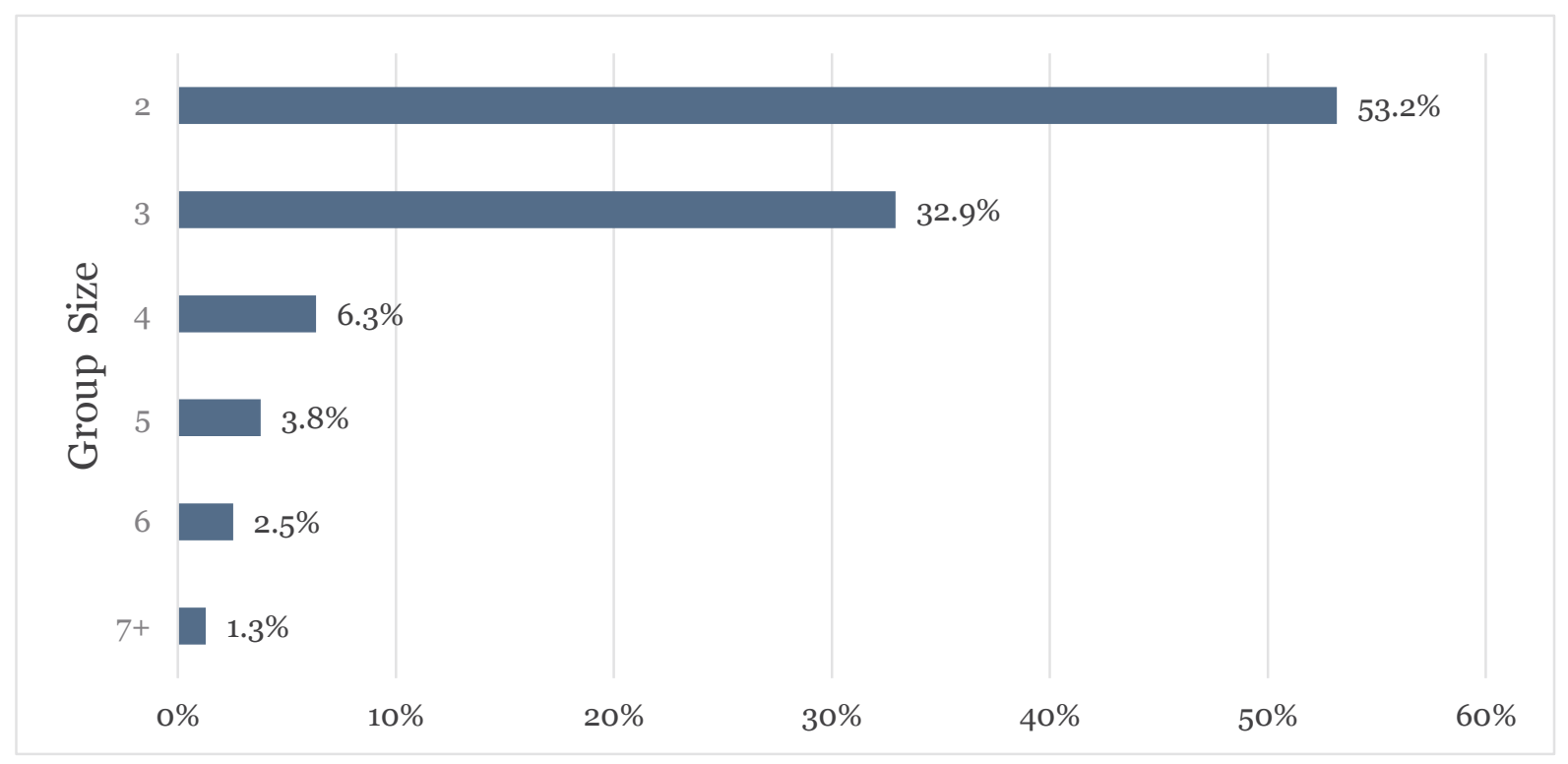

Group study snapshot data indicate that those who were working together were primarily in voluntary study groups or completing group projects (see Table 3 ). Those who were in voluntary groups did so primarily because they felt that they did better when they worked together (see Figure 3).

Table 3. Reasons for Working Together as a Group (Group Study Snapshots)

\begin{tabular}{|c|c|c|c|c|c|c|}
\hline $\begin{array}{l}\text { Working on } \\
\text { the same } \\
\text { thing? }\end{array}$ & $\begin{array}{l}\text { Club } \\
\text { activity }\end{array}$ & $\begin{array}{l}\text { Group } \\
\text { project }\end{array}$ & $\begin{array}{l}\text { Just } \\
\text { sitting } \\
\text { together }\end{array}$ & $\begin{array}{l}\text { Organized } \\
\text { tutoring } \\
\text { session }\end{array}$ & $\begin{array}{l}\text { Voluntary } \\
\text { study } \\
\text { group }\end{array}$ & Total \\
\hline $\begin{array}{l}\text { All working on the } \\
\text { same thing }\end{array}$ & 1 & 10 & & 1 & 14 & 26 \\
\hline $\begin{array}{l}\text { Some working on } \\
\text { the same thing }\end{array}$ & & 1 & & & 2 & 3 \\
\hline $\begin{array}{l}\text { None working on } \\
\text { the same thing }\end{array}$ & & & 17 & & & 17 \\
\hline Total & 1 & 11 & 17 & 1 & 16 & 46 \\
\hline
\end{tabular}




\section{Figure 3. Reasons for Forming Voluntary Study Groups (Group Study Snapshots)}

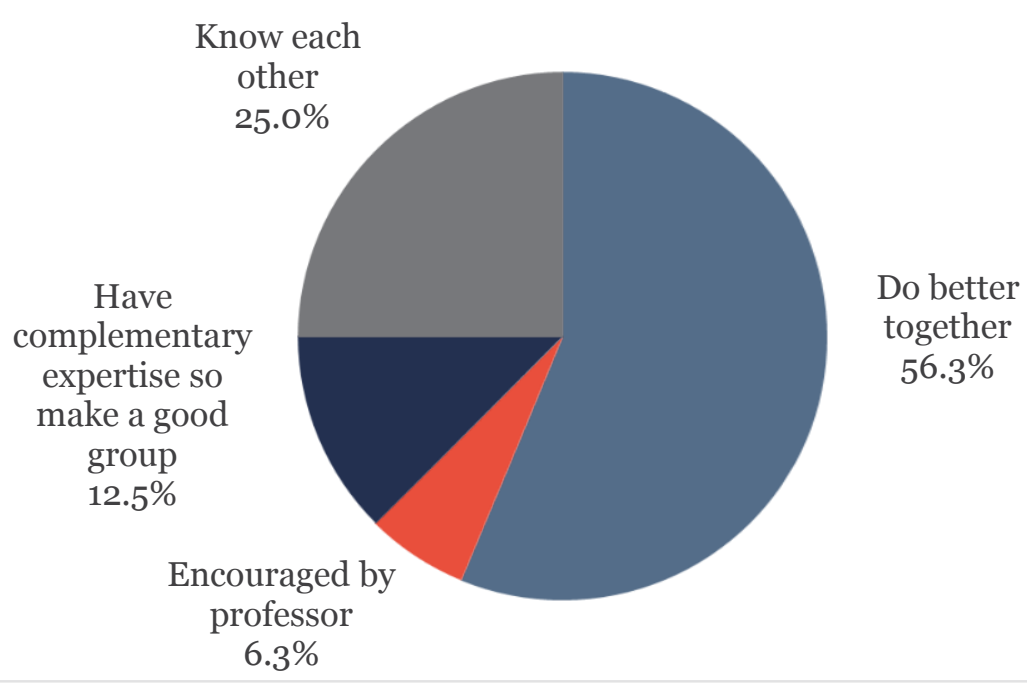

For the spot interviews and reply cards, students were asked their majors in an attempt to gather information about assignment of group projects by discipline. Spot interview data show that the most recent group projects that students worked on (35 out of 86) had frequently been assigned in liberal arts classes (see Table 4). Reply card data indicate that respondents majoring in agriculture, biotechnology and natural resources, engineering, journalism, and the sciences were often working with others when in the libraries (see Table 5). Because of the limitations of our sampling, more data would be needed to draw conclusions about the disciplines that are assigning larger numbers of group projects. ${ }^{15}$

\footnotetext{
${ }^{15}$ The National Survey of Student Engagement's annual report for 2014, "Bringing the Institution into Focus: Annual Results 2014," provides an overview of some of the characteristics of collaborative learning in higher education, including how group work varies by discipline. The report highlights that the STEM disciplines in general and engineering in particular utilize collaborative learning more frequently than the arts and humanities disciplines. National Survey of Student Engagement, "Bringing the Institution into Focus: Annual Results 2014," http://nsse.indiana.edu/html/annual_results.cfm.
} 


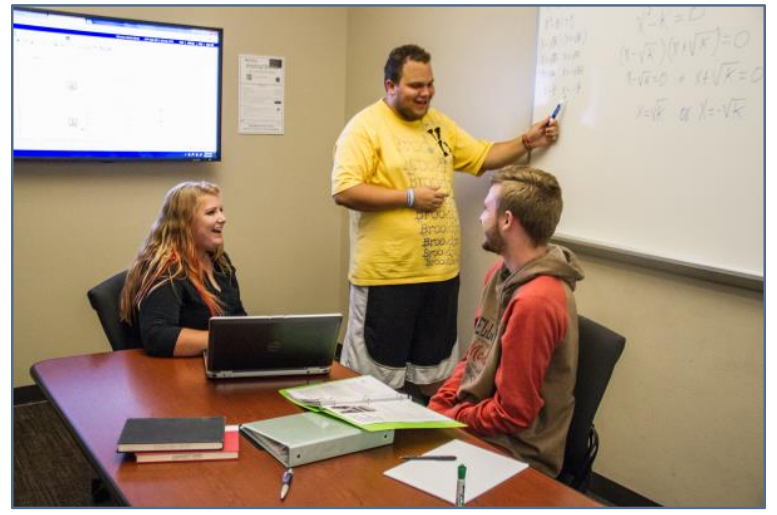

Students in a Group Study Room in the Mathewson-IGT Knowledge Center

Table 4. College/Division in Which Last Group Project Was Assigned (Spot Interviews)

\section{College/Division}

\begin{tabular}{ll}
\hline $\begin{array}{l}\text { Agriculture, Biotechnology \& Natural } \\
\text { Resources }\end{array}$ & 5 \\
Business & 4 \\
Education & 4 \\
Engineering & 13 \\
\hline Health Sciences & 5 \\
Journalism & 1 \\
\hline Liberal Arts & 35 \\
\hline Science & 86 \\
\hline Other/Unknown & 10 \\
\hline Notal & 4 \\
\hline
\end{tabular}

Students 


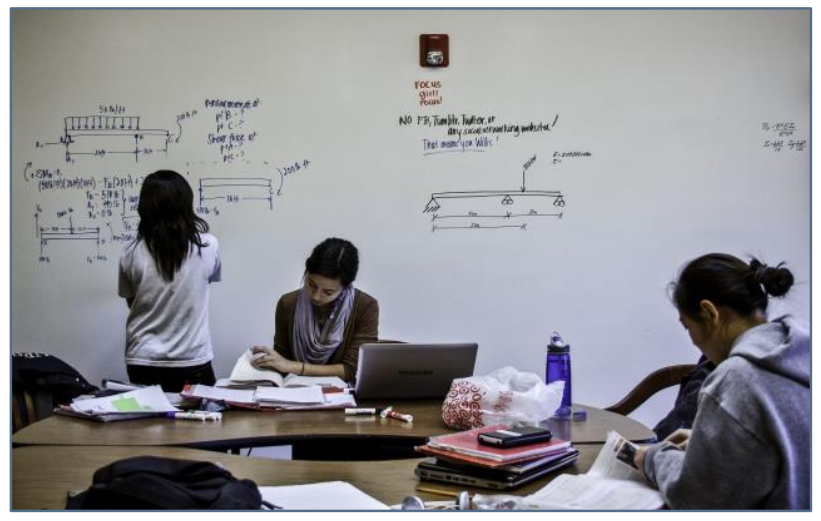

Student Using a Whiteboard Wall in the DeLaMare Science and Engineering Library

Table 5. Colleges/Divisions of Major for Students Working Alone and with Others in the Libraries (Reply Cards)

\begin{tabular}{lccc}
\hline College/Division & Alone & $\begin{array}{c}\text { With } \\
\text { Others }\end{array}$ & Total \\
\hline $\begin{array}{l}\text { Agriculture, Biotechnology } \\
\text { \& Natural Resources }\end{array}$ & 5 & 9 & 14 \\
Business & 10 & 8 & 18 \\
Education & 6 & 1 & 7 \\
Engineering & 12 & 10 & 22 \\
Health Sciences & 12 & 8 & 20 \\
Journalism & 0 & 3 & 3 \\
Liberal Arts & 17 & 10 & 27 \\
\hline Science & 6 & 13 & 19 \\
\hline Other/Unknown & 75 & 71 & 146 \\
\hline Total & 75 & 9 & 16 \\
\hline & & 71 & \\
\hline
\end{tabular}

The data suggest that students work in groups primarily when assigned a group project or when studying for an exam. Such groups on average include three people. The data are not conclusive but indicate a variable rate of assigning group projects in different majors or program areas. 


\section{Where Groups Work}

In spot interviews, students who had most recently worked with other people indicated a strong preference for the main library (13 of 31) over the other locations they chose, which included their homes or dorm rooms (8 of 31), the science library ( 2 of 31 ), and other campus locations ( 8 of 31 ; see Table 6 ).

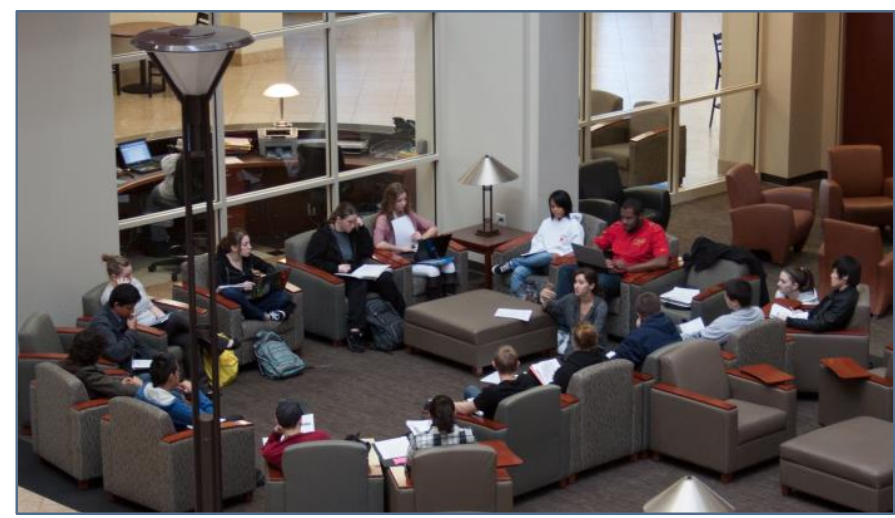

Students in the Atrium of the Mathewson-IGT Knowledge Center

Table 6. Locations When Working Alone and with Others (Spot Interviews)

\begin{tabular}{lcccccc}
\hline & $\begin{array}{l}\text { Main } \\
\text { Library }\end{array}$ & $\begin{array}{l}\text { Science } \\
\text { Library }\end{array}$ & $\begin{array}{l}\text { Other } \\
\text { Campus } \\
\text { Location }\end{array}$ & $\begin{array}{l}\text { Home/ } \\
\text { Dorm }\end{array}$ & $\begin{array}{l}\text { Off- } \\
\text { Campus }\end{array}$ & Total \\
\hline Alone & 16 & 14 & 24 & 1 & 55 \\
With Others & 13 & 2 & 8 & 8 & 31 \\
\hline Total & 29 & $\mathbf{2}$ & $\mathbf{2 2}$ & $\mathbf{3 2}$ & $\mathbf{1}$ & $\mathbf{8 6}$ \\
\hline
\end{tabular}

The selection of a location for group work is related to a pattern in spot interview respondents of conducting group work in person (50 responses) or through a mix of online and in-person work (12 responses). Two respondents reported working online only, using Google Drive and the course management system (CMS) to support that work. For those who met in person, email provided support while a few used Google Drive or the CMS.

Students responding to spot interviews who reported choosing the libraries as a study location said they did so for the academic affordances of the space, whether ambient (quiet, privacy, others studying) or technological (computer, printer, and software availability; see Table 7). 
Table 7. Reasons for Choosing a Study Location (Spot Interviews)

\begin{tabular}{|c|c|c|c|c|c|c|}
\hline & $\begin{array}{l}\text { Main } \\
\text { Library }\end{array}$ & $\begin{array}{l}\text { Science } \\
\text { Library }\end{array}$ & $\begin{array}{l}\text { Other } \\
\text { Campus } \\
\text { Location }\end{array}$ & $\begin{array}{l}\text { Home/ } \\
\text { Dorm }\end{array}$ & $\begin{array}{l}\text { Off- } \\
\text { Campus }\end{array}$ & Total \\
\hline $\begin{array}{l}\text { Academic } \\
\text { affordances - } \\
\text { ambiance }\end{array}$ & 16 & & 3 & 7 & & 26 \\
\hline $\begin{array}{l}\text { Academic } \\
\text { affordances - } \\
\text { technology }\end{array}$ & 4 & 1 & 5 & 1 & & 11 \\
\hline Assigned & & & 5 & & & 5 \\
\hline Comfortable & 3 & & & 2 & & 5 \\
\hline Convenient & 1 & & 4 & 19 & 1 & 25 \\
\hline Familiar & 5 & & 3 & 1 & & 9 \\
\hline $\begin{array}{l}\text { Family/ } \\
\text { personal } \\
\text { obligations }\end{array}$ & & & & 2 & & 2 \\
\hline $\begin{array}{l}\text { Seats } \\
\text { available } \\
\text { here }\end{array}$ & & & 1 & & & 1 \\
\hline Other & & 1 & 1 & & & 2 \\
\hline Total & 29 & 2 & 22 & 32 & 1 & 86 \\
\hline
\end{tabular}

Reply card responses indicate that respondents working in group study rooms in the main library are more attached to that particular kind of accommodation than respondents working in other parts of the library. Of the 30 who were working in a study room, 14 indicated that they would go to another study room if forced to leave the area in which they were then seated, whereas 86 of the 113 respondents who were in other locations in the main library indicated overwhelmingly that they would go to another free spot if asked to move. Moreover, of the 30 reply card respondents using study rooms in the main library, 14 said that they chose those spaces because they supported gathering, talking out loud, and a degree of privacy. What we speculate about "privacy," however, is that respondents are more concerned with the isolation of noise than creating seclusion for individuals. 
Group study snapshot data reveal a similar pattern with some additional emphasis on ambiance (including quiet, secluded, comfortable, lighting) and convenience of location (see Table 8). The availability of technology is more important in the science library than in the main library; of the 29 groups who were working on the same thing, 5 out of 13 in the science library chose that location for its technological affordances and only 1 out of 16 cited this reason in the main library. In addition, these snapshots reveal that relatively "low" technologies, such as tables and whiteboards, are used more by groups who are working together than "high" technology items like computers and screens.

According to group study snapshot data, students (15 out of 46 responding groups) see a need for more seats and tables, and perhaps better furniture overall, to accommodate group work in the libraries. They also call for more outlets (9), more whiteboards and markers (8), better lighting (5), and better temperature control/air quality (5).

Table 8. Reasons for Choosing a Study Location in the Libraries (Group Study Snapshots)

\begin{tabular}{|c|c|c|c|c|c|c|}
\hline & $\begin{array}{l}\text { Just } \\
\text { sitting } \\
\text { together }\end{array}$ & $\begin{array}{l}\text { Voluntary } \\
\text { Study } \\
\text { Group }\end{array}$ & $\begin{array}{l}\text { Group } \\
\text { Project }\end{array}$ & $\begin{array}{l}\text { Club } \\
\text { Activity }\end{array}$ & $\begin{array}{l}\text { Organized } \\
\text { Tutoring } \\
\text { Session }\end{array}$ & Total \\
\hline Ambiance & 8 & 4 & 4 & & & 16 \\
\hline $\begin{array}{l}\text { Available } \\
\text { space }\end{array}$ & 1 & 3 & & 1 & 1 & 6 \\
\hline Comfort & 3 & & & & & 3 \\
\hline Convenience & & 5 & 4 & & & 9 \\
\hline Technology & & 3 & 3 & & & 6 \\
\hline $\begin{array}{l}\text { Their regular } \\
\text { place }\end{array}$ & 4 & & & & & 4 \\
\hline Whiteboards & & 1 & & & & 1 \\
\hline $\begin{array}{l}\text { No particular } \\
\text { reason }\end{array}$ & 1 & & & & & 1 \\
\hline Total & 17 & 16 & 11 & 1 & 1 & 46 \\
\hline
\end{tabular}


Overall, group work appears to be done face-to-face and is not uniformly dependent on technology but does call for space that allows respondents to gather and make some noise. Libraries attract students who must work in groups due to collaborative study or assignments or who prefer to do so due to their own expectations of better outcomes. This drives a felt need for the expansion of space that supports sitting and working with others.

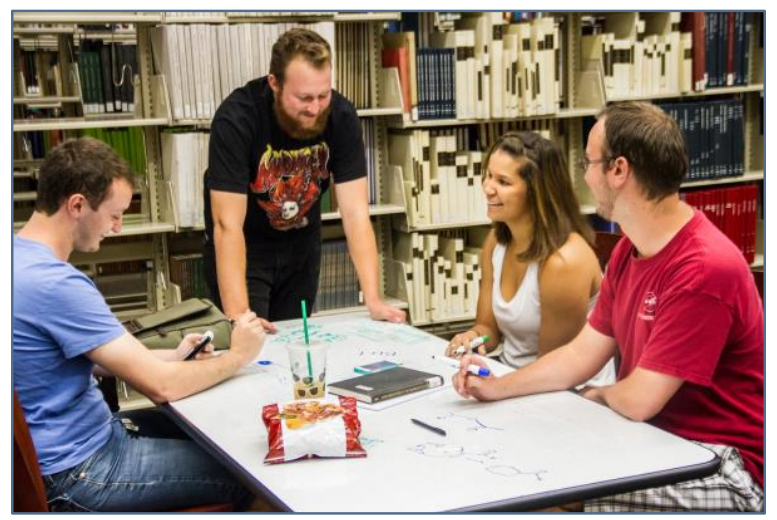

Students at a Whiteboard Table in the Mathewson-IGT Knowledge Center

\section{Groups Who Are "Just Sitting Together"}

Data from the group study snapshots suggest that there are many more people just sitting together in groups in the main library ( 16 of 32 groups) than in the science library (1 of 14). These students have a range of reasons for selecting space, including the ability to talk without bothering others. A small but significant number of those who are just sitting together do collaborate from time to time, according to group study snapshot data; 7 of 17 groups-about 40 percent -reported having helped each other with schoolwork while otherwise just sitting together.

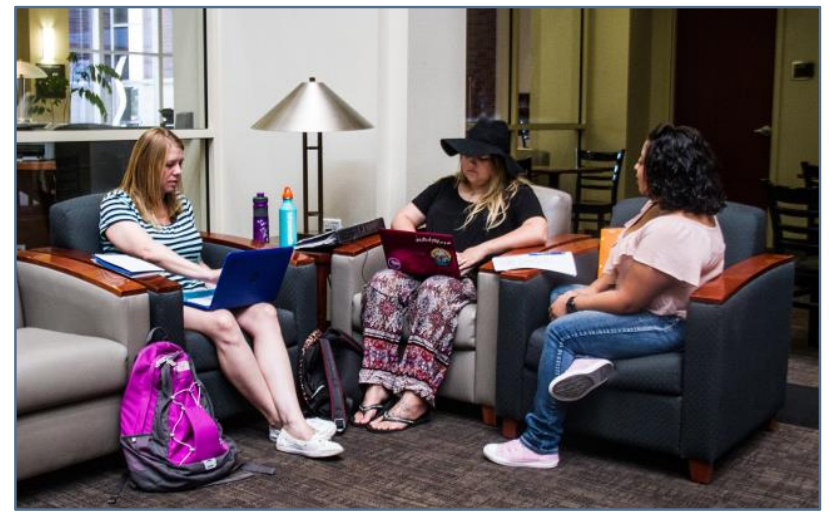

Students in the Atrium of the Mathewson-IGT Knowledge Center 


\section{Significant numbers of students are deeply engaged in academic work and choose to sit with friends who are conducting independent tasks. In many cases, students who are "just sitting together" actually do help each other with their academic work.}

\section{Conclusions and Opportunities}

The information gathered in the course of this project was limited by constraints on time and resources; however, it did suggest some actionable conclusions. These include:

- A significant majority of people in the main library and the science library are engaged in academic work, many of them working or just sitting in groups.

- Students sit with others mainly to have company. A significant number help each other on an informal or casual basis. A small number are together because they are working on an assigned group project or because they have formed a voluntary study group.

- Group work is assigned across the curriculum, not only in certain courses or programs, and may take many forms.

- Students work in groups across campus and in off-campus locations, where they find that a combination of convenience and conditions makes their work possible.

- On campus, the main library attracts a noticeably large number of students to sit or work together, straining available facilities and equipment.

These conclusions stimulate ideas about how to proceed in decision-making about library spaces and services that support student work practices.

An initial goal of the project was to expand support for group work by understanding more about it. While this remains an objective, the information we collected suggests that there are policy questions to answer before making plans for modifying library spaces. Indeed, the information in this report provides library leadership with a basis for discussion toward a policy decision about the kinds of group work that the library will support with its limited resources. The decision might be to support any kind of group whatsoever, from two students relaxing over a cup of coffee to large groups conducting complex projects requiring library resources. On the other hand, the decision may be to use library resources only to support those groups that are engaged in shared academic work. Or, library leadership might choose to select some portion of the group work continuum toward which to funnel resources. In any case, it was thought that an initial policy decision was needed to guide subsequent decisions and focus the work of librarians and library staff on addressing some of the needs identified during the project. 
We also thought the results should be shared more widely, and beyond the library, because the study has broad implications for the institution and the campus in general. Such discussion might take up the question of supporting group work in all its forms throughout the campus and not just in the library. This could mean accommodating the group work that is most connected to the libraries' core mission inside the libraries while finding ways to support much larger numbers of students who want to work in groups, and to make this even more convenient for students by distributing group spaces throughout the campus. It could also mean sharing the responsibility and the expense of providing these spaces with other university units.

The study yielded information about a variety of requirements that could usefully be considered in planning the expansion or renovation of group study space. The data indicate that areas for group study should afford:

- Room for as few as two and as many as six or more people to sit and work in a comfortable, well-lighted space where they can spread out their materials

- Building materials and configurations that make it possible for students in groups to talk to each other without disturbing those sitting nearby who need relative quiet

- Whiteboards or other technology for students to share information or work out problems

- Basic infrastructure so that students can charge devices and connect to the Internet

Regardless of any decision to expand group study space, our findings support the continued provision of quiet, individual study spaces. There is a clear need for some group space, and possibly increased group space, but there is also ample evidence that many students still work alone. 


\section{Works Cited}

Andrews, Camille, and Sara E. Wright. "Library Learning Spaces: Investigating Libraries and Investing in Student Feedback." Presentation at the ACRL 2015 Conference, Portland, OR, March 25-28, 2015. http://www.ala.org/acrl/sites/ala.org.acrl/files/content/conferences/confsandpreconfs/ 2015/Andrews Wright.pdf.

Bailin, Kylie. "Changes in Academic Library Space: A Case Study at the University of New South Wales.” Australian Academic \& Research Libraries 42, no. 4 (2011): 342359.

Bersani, Alison, Judi Briden, Sue Cardinal, and Katie Clark. "Study Groups in Libraries: Exponential Benefits.” In Studying Students: A Second Look, edited by Nancy F. Foster and Susan Gibbons, 123-38. Chicago: ACRL Press, 2013. http://hdl.handle.net/1802/28781.

Bryant, Joanna, Graham Matthews, and Graham Walton. "Academic Libraries and Social and Learning Space: A Case Study of Loughborough University Library.” Journal of Librarianship and Information Science 41, no. 1 (2009): 7-18.

Crook, Charles, and Gemma Mitchell. "Ambience in Social Learning: Student Engagement with New Designs for Learning Spaces." Cambridge Journal of Education 42, no. 2 (2012): 121-139.

Hall, Katharine, and Dubravka Kapa. "Silent and Independent: Student Use of Academic Library Study Space." Partnership: The Canadian Journal of Library and Information Practice and Research 10, no. 1 (2015).

https://journal.lib.uoguelph.ca/index.php/perj/article/view/3338/3506\#VcILNvlVhBd.

Harrop, Deborah, and Beatrice Turpin. "A Study Exploring Learners' Informal Learning Space Behaviors, Attitudes, and Preferences.” New Review of Academic Librarianship 19, no. 1 (2013): 58-77.

Holder, Sara, and Jessica Lange. "Looking and Listening: A Mixed-Methods Study of Space Use and User Satisfaction.” Evidence Based Library and Information Practice 9, no. 3 (2014): 4-27.

National Survey of Student Engagement. "Bringing the Institution into Focus: Annual Results 2014." http://nsse.indiana.edu/html/annual results.cfm. 
Whitchurch, Michael J. "Evaluating Group Use of the Information Commons." College \& Undergraduate Libraries 16, no. 1 (March 30, 2009): 71-82. 